\title{
Misprisions of London
}

\section{Dana Arnold}

Early nineteenth-century London is often seen as the architecturally poor cousin of other European cities. The backward glance of the historian presents a story of unrealised urban visions and abandoned grand projects rather than focusing on what was actually achieved and built. Contemporaries viewed things differently; London was 'the new Rome', the first city of a new Empire, and the new classical architecture and urban planning made reference to its ancient counterpart. The nostalgia for a temporally distant Rome was predicated on the invented memory of its architectural splendours. But ancient Rome was in ruins. For London to equal the status of Rome would it too need to become a ruin? Did its future lie in fragments?

My interest is in the relationship between London and its historical misprisions, by which I mean our failure to appreciate the city's identity. The concept of the ruin is essential here as the veneration of the ancient world was built on its wreckage. Classical Rome was central this enduring admiration of antiquity, which had been a mainstay of European culture since the Renaissance. ${ }^{1}$ Importantly here, the eternal city provided substantial inspiration for the urban development of early 
nineteenth-century London. This is manifest in the grandiose architectural schemes of the Prince Regent and the wide-ranging metropolitan improvements aimed at ensuring the aesthetic of London both rivalled its European counterparts and projected an identity appropriate for the first city of empire. ${ }^{2}$ References to Rome were manyfold. Architecture articulated with the classical orders and other all'antica details abounded across the everexpanding capital. Perhaps most obviously, the Marble Arch and the Arch at Constitution Hill drew on those of the Roman Emperors Titus and Constantine respectively. Even the nomenclature of new buildings reflected the eternal city, albeit sometimes through a somewhat idiosyncratic lens. The configuration of the Hyde Park Screen and the Arch at Constitution Hill was hailed as a propylaea, despite its evident Roman antecedents. ${ }^{3}$ The Pantheon on Oxford Street drew its inspiration from its ancient roman counterpart, which had survived almost intact. ${ }^{4}$ Indeed, this much venerated roman remain made an additional reprise in The Colosseum in Regent's Park designed in 1823 by Decimus Burton. ${ }^{5}$ The deliberate misnomer was to avoid confusion between the two edifices. For the builders of modern London, the imagined connection with Rome triumphed over historical accuracy. In this way, the majesty of modern London was signalled by resurrected ruins and invented memory, and the city's identity rested on this slippage between time and space. 
The relationship between an imagined classical past and the construction of a modern identity for London has been explored elsewhere. ${ }^{6}$ My concern here is with the construction of a future identity or legacy for the modern metropolis through the trope of the ruin. This reveals a different kind of invented memory that inscribes London with timelessness and monumentality. These qualities propel the city into the future in order that it becomes one of the celebrated monuments of an antiquity that is yet to come. Two well-known early nineteenthcentury examples are indexical of the ways ruins can project social, political and cultural distinctiveness in an urban context. Joseph Gandy's Bird's eye view of the Bank of England (1830) emphasises the monumentality of John Soane's design and the institution itself through the illusion of decay (plate 1). Similarly, Gustave Doré's image of Thomas Babington Macaulay's fictive New Zealander resting on a broken arch of London Bridge speaks of the architectural devastation of the first city of empire (plate 2). Both Gandy and Doré's images are of ruins of an antiquity that is yet to come.

I take my lead from the long-standing trope of projecting cities into the future through a vision of their destruction. The ideological use of ruins as a means of expressing identity that can be traced back to Thucydides' comments on archaic and classical Sparta: 
If the Spartans' city were to become deserted, and only the temples and foundations of buildings were left, I think that the people of that time far in the future would find it difficult to believe that the Spartans' power had been as great as their fame implied (and yet they inhabit two-fifths of the Peloponnese, and are in command of all of it as well as of many allies outside it; nevertheless, it has not been merged (synoecised) into a city, nor does it possess costly temples and buildings, but consists of a number of villages in the early Greek manner, and would seem an inferior place), whereas if the same thing were to happen to Athens, from its visible remains one would assume that the city had been twice as powerful as it actually is. ${ }^{7}$

Thucydides identifies the physical, archaeological remains as a key element in a city's future identity. Crucially for us, he speculates that the ruins of the classical architecture of Athens will augment the city's status.

The ideological properties of ruins and ruination are picked up on by the philosopher Edmund Burke's discussion of London in A Philosophical Enquiry into the Origin of Our Idea of the Sublime and Beautiful (1757):

We delight in seeing things, which so far from doing, our heartiest wishes would be to see redressed. This noble 
capital, the pride of England and of Europe, I believe no man is so strangely wicked as to desire to see destroyed by a conflagration or an earthquake, though he should be removed himself to the greatest distance from the danger. But suppose such a fatal accident to have happened, what numbers from all parts would crowd to behold the ruins, and amongst then many who would have been content never to have seen London in its glory? ${ }^{8}$

Burke uses the example of London in ruins as part of his discussion of 'The effect of Tragedy' in the first part of his Enquiry. ${ }^{9}$ In his discussion of the imitation of tragedy, he is concerned with the question of why we want to look at, or indeed gain pleasure from seeing represented, that which we would not wish to see in actuality:

In imitated distresses the only difference is the pleasure resulting from the effects of imitation; for it is never so perfect, but we can perceive it is imitation, and on that principle are somewhat pleased with it. [...] I believe that this notion of our having a simple pain in the reality, yet a delight in the representation, arises from hence, that we do not sufficiently distinguish what we would by no means choose to do, from what we should be eager enough to see if it was once done. ${ }^{10}$ 
Burke's observations might appear rather obvious. But he does raise the important issue of why we find these kinds of potentially disturbing imitations satisfactory and this helps us to understand why we are attracted to the trope of the ruin. Indeed, Thucydides and Burke present a powerful combination of the ideological and archaeological presence of ruins and why they endure as allegories in western verbal and visual culture.

My focus here is on two well-known early nineteenthcentury examples that combine the ideological and archaeological presence of ruins. They are indexical of the ways ruins can encode and promote social, political and cultural urban identities. Sir John Soane commissioned Joseph Gandy to depict A Bird's-eye view of the Bank of England (1830), first exhibited at the Royal Academy in $1830 .{ }^{11}$ Soane also displayed the work in his house and used it to illustrate his Royal Academy lectures. This watercolour is often referred to as 'The Bank of England in ruins' but neither Soane nor Gandy used this title. That said, Soane must have anticipated viewers of this work to interpret it as a visualisation of future ruin. As we will see, Soane's interest in ruins spanned his entire career. Indeed the archaeological metaphor was a dominant feature of his architectural writing and practice and Soane's taste as a collector. ${ }^{12}$ 
Thomas Babington Macaulay's comment on the Roman Catholic Church, made only ten years after Gandy's vision of The Bank of England speaks of decline:

And she may still exist in undiminished vigour when some traveller from New Zealand shall, in the midst of a vast solitude, take his stand on a broken arch of London Bridge to sketch the ruins of St. Paul's. ${ }^{13}$

But this time the architectural devastation imagined by Macaulay speaks of the end of the empire and the then most populated city in the world as deserted. Macaulay's prophecy of ruins was visualised by the French artist and illustrator Gustave Doré several decades later. The engraving first appeared as one of the many illustrations in Gustave Doré and Blanchard Jerrold's book based on Macaulay's imaginary visitor entitled 'Macaulay's New Zealander' in London: A Pilgrimage, 187172.

The connective tissue between my examples is the formation and promotion of the identity of modern London, and in particular the image of the metropolis in its role as first city of empire and as a thriving commercial centre. But there is special emphasis here on the City of London, which had its own distinctive identity in the early decades of the nineteenth century. The relationship between the central, national government based 
in Westminster and the City of London was complex. The civic pride and financial autonomy of the City and its institutions that covered all trades, including banking, gave it a distinctive, forward-looking identity as the economic engine of the nation's greatness. However, many of the middle and merchant classes who thrived in the City were excluded from the processes of national government. This gave rise to significant tension between the City of London and the ruling elite in Westminster, which was partly resolved by the 1832 Reform Act. ${ }^{14}$

Indeed, Soane and Macaulay choose to represent as ruins key buildings that encapsulate the City's identity. Moreover, the monumentality and importance of both the building and the institution of the Bank of England are enhanced through their impending decay. And the essential role of the City of London is recognised by Macaulay, albeit in his apocalyptic vision as he describes the ruination of both London Bridge and St Paul's. Both Soane and Macaulay see London's modernity as expressed through the future vision of its architectural fragments and ruins. Images and imaginings of architecture in fragments are undeniably powerful, but my interest goes beyond the aesthetic of the ruin as an object. Using Walter Benjamin's idea that 'Allegories are, in the realm of thoughts, what ruins are in the realm of things', I aim to read the ruins of London as a process rather than an aesthetic. ${ }^{15}$ Ruination becomes a critical tool through which we can explore the misprisions of London's 
present and future through fragments of (invented) memory.

This anachronistic juxtaposition of a twentieth-century German thinker and the specific instance of imaginings of early nineteenth century London is representative of the enduring presence of ruins in western thought. We have looked back to Thucydides and Burke to explore the meaning of ruins. Benjamin, and indeed Speer, who we will encounter later on, propel this discourse forward. Whilst London remains the focus, we see how ruins operate as the process of the slippage between time and space and as a critical tool for understanding the projection of a future nostalgia for the present. Indeed, Benjamin's notion that the temporality of a ruin is the product both of the building's destruction and its original construction is helpful here. In this way we see how on passing through the process of ruination, a building betrays simultaneously its richest and most economical significance and meaning. We can see how these ideas operate in both Bird's-eye View and Macaulay. For instance, we see the Bank of England in both a state of construction and deconstruction - the building appears to pass through time. Similarly, each of these visions of a ruined London underscore the importance of the architecture that is now destroyed. In this way, Benjamin helps us to understand the slippage between space and time that ruins represent and how their allegorical presence can project urban identities into the future. 


\section{Soane}

Sir John Soane was one of the leading architects of his generation who was responsible for the shaping of modern London. ${ }^{16}$ Alongside his private commissions, Soane worked as an attached architect for the Office of Works and was responsible for many public buildings that shaped the modern metropolis. ${ }^{17}$ In addition, Soane was appointed architect and surveyor to the Bank of England in 1788 and his work at the bank spanned most of his career. ${ }^{18}$ Indeed, Soane resigned his position in 1833 only four years before his death. ${ }^{19}$ During Soane's forty-five years in post, the bank was almost entirely rebuilt and substantially expanded. ${ }^{20}$ Alongside his successful practice, Soane was a pioneer in the development of the architectural profession and trained many pupils at his home/office in Lincoln's Inn Fields. ${ }^{21}$ From 1808 until his death in 1837 he extended no. 12 Lincoln's Inn Fields into a house/museum that eventually spread to no. 14 . The much altered, internal architectural arrangement played on the effects of space and light and remains a testament to his ingenuity as an architect in the combination of modern and all'antica design elements. Soane was almost as renowned as a collector as he was an architect, and he housed his vast collection of antiquities (both originals and copies), prints, drawings and books at Lincoln's Inn Fields. ${ }^{22}$ This amalgamation of fragments of the 
ruins of the past was essential for Soane's architectural practice. Moreover, he ensured his legacy would survive into the future as in 1833 , the same year as he resigned from the Bank of England, Soane negotiated an Act of Parliament to preserve the house and collection intact for the benefit of 'amateurs and students' in architecture, painting and sculpture. ${ }^{23}$ The richness of the collection and ingenuity of its display are not the concern here, nor is Soane's pedagogical purpose in creating his house/museum. However, one aspect of the display brings us back to the Bank of England and Gandy's Bird's-eye View. Soane collected cork models of the ruins of ancient architecture. In 1826 he acquired a model of the ruins of Pompeii and the distinctive aesthetic of this relic from the classical past has resonance with Gandy's Bird's-eye View. Indeed, in 1834 Soane completed his new Model Room and placed both the model and a ground plan of the Bank of England in close proximity. In this way, the similarities between the two works become more compelling. This anachronistic juxtaposition perhaps underscores Soane's future vision of the ruins of his life's work as being equal to its antecedents from antiquity.

Soane's practice and pedagogy collided when, in 1806, he succeeded George Dance the Younger as Professor of Architecture at the Royal Academy. He was required to deliver twelve lectures annually and these were assembled between 1809-10. The relationship between ruins and reminiscence 
comes to the fore in Soane's decision to illustrate his lectures with more than one thousand images of buildings and plans. ${ }^{24}$ Gandy's image of A Bird's-eye view of the Bank of England was one of these illustrations. It is important to remember that the Bank of England was one of Soane's principal architectural commissions that dominated his career. But he chose to present this key work as a ruin of the future. The building was extant and intact and Soane entrusted its visual fragmentation into ruins to Gandy's imagination. Indeed, Gandy's representation of the Bank of England is not without its own visual intricacies. As Daniel Abramson notes of Gandy's bird's eye view:

The view inventively conflates conventions of the Renaissance aerial cutaway perspective with the eighteenth-century Piranesian ruinscape to create an image of the Bank of England ambiguously both in ruins and under construction. ${ }^{25}$

Crucially, for this reading of Gandy's image to work we need to have knowledge of the complete whole to understand the building in both its pre and post finished state. More significantly, to my mind, is the fact that Gandy's image negates the present state of the bank. And this signals my interest in the slippage between past present and future identities of the Bank of England. Indeed, it is important to think more generally about 
other visual conventions where the original, intact building was not known as this reveals further complexities in the approaches to the representation of the fragment and the ruin. For our purposes here, we might divide these views into the architectonic and the romantic vision of the relics of the past, all of which were very well represented in Soane's collection. The architectonic vision seeks to reconstruct a building. This might concentrate on the structure as a whole or on individual fragments. We see this, for instance, in the work of Andrea Palladio or Thomas Major. ${ }^{26}$ This system of architectural drawings using perspective views, orthogonal elevation, details and working drawings was not merely imitative. Instead buildings were disembodied and dissected, order was imposed on chaos - marks on paper evoked the built fabric. Thomas Major's studies of the Temple of Neptune at Paestum and its Doric order demonstrate this technique. Here the ruined edifice is reconstructed in orthogonal elevation and is presented out of its physical context. There is no surrounding landscape and there is no texture to the stone or patina of age. By contrast, the romantic vision of ruins makes no attempt at reconstruction. Instead, the effects of the time are celebrated and ruination becomes an aesthetic. ${ }^{27}$ In this way, crumbling masonry and overgrown vegetation present a picturesque ideal of the past where they might otherwise have spoken of decay. This vision of the classical past came to prominence in the mid-eighteenth 
century through the work of artists and antiquarians such as Clérisseau and Piranesi. ${ }^{28}$ If we compare Piranesi's views of the Temples at Paestum to those of Major we see they are at once an image of the actuality of the ruins themselves and a carefully constructed re-performance of the temples, which unlike Major's studies places the temples firmly in the past. ${ }^{29}$ The scale and size of the temples in relation to the size of the print is important here as they fill the frame, and the inclusion of human figures that are dwarfed by the massive bulk of the buildings underscores the awesome appearance of the temples. ${ }^{30}$ For Soane the architectonic studies of antiquity facilitated the inclusion of certain stylistic elements into his modern designs, as seen in the example of Tivoli Corner discussed below. Conversely, the romantic visions of antiquity also influenced Soane's view of his own work. In 1798 Soane completed the Rotonda of the Bank of England. In the same year Gandy produced a watercolour of it showing the structure as if it was a Roman ruin. This drawing was exhibited at the Royal Academy in 1832, under the romantic title of Architectural Ruins $-A$ Vision.

As we have seen, for Benjamin the temporality of a ruin is the product both of the building's destruction and its original construction and the process of ruination reveals the rich layering of its various meanings. Moreover, ruins become an allegory for the transient nature of human endeavour; whatever 
we build will ultimately be destroyed. The ephemerality of human achievement, was of concern to Soane, Consequently, Soane's decision to present his life's work at the Bank of England as a ruin deserves further investigation beyond Gandy's aesthetic choices and Benjamin helps us to do this. Not least, the depiction of the Bank of England surely begs us to question why Soane, a nineteenth-century architect whose work was so closely intertwined with the production of modern London and the establishing of architecture as a profession, would wish to do this? Surely ruined buildings can be seen as negations of architecture. But I wonder, given Soane's fascination with the classical past, if he designed his buildings with their future ruination in mind.$^{31}$ Indeed, he was as concerned with the ephemerality of his own architectural works as he was with their future posterity. In this way Soane's architecture can be seen as something that would tell the story of an ideology. We must remember that Soane, through his knowledge of the architecture of the ancient classical world, was aware of the powerful presence of ruins. In this way, as an architect who drew inspiration from antiquity, Soane was part of a process through which ruins lay down a kind of ideological deposit for the future that awaits interpretation.

We can see this process at work in Soane's design for the Bank where the use of all'antica elements is more than just an aesthetic choice. For instance, the extension of the exterior wall 
of the bank to the north-west, at the junction of Lothbury and Princes Street typifies Soane's use of antique sources in his very modern designs. This expansion of the bank formed an irregularly shaped plot where the building was now seen from a number of viewpoints, making a right-angled corner an architecturally clumsy solution. Soane's ingenious answer to this design problem was what is known as 'Tivoli Corner'. Soane had visited the Temple of Vesta at Tivoli when on his grand tour in 1778-9. Its unusual, circular form provided the ideal architectural solution to the problem of making a building turn a corner in a visually pleasing way. Importantly here, a fragment of a ruin is integrated into a modern design intended to project the identity of the Bank of England into the future. But Tivoli Corner is also an allegory that makes me think about future ruins and reminiscence. Gandy's image of the Bank of England can then be seen as predicting its ruination, or, if you will, embedding it in the extant building. In this way we can also see Tivoli Corner as an ideological deposit - part of a process rather than an aesthetic. The slippage between past, present and future becomes an allegory that resides in the spaces of historical memory and the imagination.

\section{Imagination}

The place of the ruin in the historical imagination stems in part from the European tradition of 'the cult of the ruin'.$^{32}$ Here the 
architectural remains of the past were aestheticised to appeal to the visual sensibilities of the elite. Taking their lead from Renaissance antiquarians such as Raphael and Palladio, European Grand Tourists admired and consumed the remnants of classical antiquity. Their interpretation of this ideological deposit places the ruin somewhere between myth and reality and raises questions about notions of authenticity. This can be seen, for instance, in the popularity of the folly in English eighteenthcentury landscape garden design - a sort of modern ruin that linked past and present, and laid down an ideological legacy for the future. We can see examples of these in the work of William Kent or Robert Adam. ${ }^{33}$ These were either completely new build or an amalgam of fragments of the past in a new configuration. These follies embedded ruination and decay into the visual lexicon of architectural design. Follies were, in the Benjaminian sense, merely aesthetic symbols. As ruins became an aesthetic they no longer operated as a critical tool to explore the ephemeral nature of existence and so their allegorical meaning was eclipsed.

The ambiguities and interchangeability between 'mock' and 'real' ruins works to disrupt our relationship with the past. Here again we find Soane's fascination with fragments and ruins, which was certainly not confined to his work at the Bank of England. At his country house, Pitzhanger Manor in Ealing, he pretended that a mock-classical ruin was a Roman temple he had 
discovered at the bottom of the garden. ${ }^{34}$ His townhouse no. 13 Lincoln's Inn Fields includes the 'Monk's Yard', a mock-ruin assembled from medieval fragments of the Palace of Westminster. Equally, the numerous artefacts from or representing the past on display are an essential component of his didactic collection. Some are authentic, others are copies and many of them are fragments. All of this might help us to understand and interpret Soane's wish to present his life's work at The Bank of England as a ruin. But I do not wish to infer any kind of intentionality on the part of Soane without further evidence.

In a remarkably vivid vision of the future Soane gives us some strong hints about his interpretation of the relationship between memory, history and the ruin in his Crude Hints Towards the History of My House. ${ }^{35}$ In this unpublished text Soane imagines an antiquary from the future inspecting the fragments of his house in Lincoln's Inn Fields. And I wonder if this is also an 'ideological deposit' laid down by Soane. The imaginary archaeologist tries to work out what the ruins might have been conjecturing if they were, for instance, the remains of a monastery, a Roman temple, a magician's lair, or the house of a persecuted artist:

In this age of research when the Connoisseur and the Antiquary find a lively interest in whatever relates to 
former times...so much notice has been taken of the ruins and very extensive assemblages of fragments of ancient works partly buried and in some degree attached to a building in this metropolis apparently of later date [in Lincoln's Inn Fields (del.)] - to rescue this work from its present uncertain origin and that the public should be fully [better] informed respecting these ruins and be led to have an interest in them, I shall collect together the various conjectures which have been made respecting this building and also the data on which these speculative opinions have been raised ... From the style of some parts of the Architecture this work has been supposed anterior to the time of Augustus ... it is to be observed that notwithstanding this building consisted of several stages or stories ... O man, man, how short is thy foresight. In less than half a century - in a few years - before the founder was scarcely mouldering in dust, no trace to be seen of the artist within its walls, the edifice presenting only a miserable picture of frightful dilapidation - oh could the dead but leave for a moment their quiet mansions, \& but look out of their graves what hell could equal their torments!

Here, Soane makes me think of Wittgenstein's remarks about culture: 
Just as a man cannot report his own death when it happens, but only foresee it and describe it as something lying in the future. So it might be said: If you want to see an epic description of a whole culture, you will have to look at the works of its greatest figures, hence at works composed when the end of his culture could only be foreseen, because later on there will be nobody left to describe it. ${ }^{36}$

\begin{abstract}
Albeit that they are unlikely bedfellows, both Soane and Wittgenstein explore the slippage between space and time as a means of understanding the 'ideological deposits' laid down for future interpretation.
\end{abstract}

\title{
Macaulay
}

Nor do we see any sign which indicates that the term of her long dominion is approaching. She saw the commencement of all the governments and of all the ecclesiastical establishments that now exist in the world; and we feel no assurance that she is not destined to see the end of them all. She was great and respected before the Saxon had set foot on Britain, before the Frank had passed the Rhine, when Grecian eloquence still flourished at Antioch, when idols were still worshipped in the temple of 
Mecca. And she may still exist in undiminished vigour when some traveller from New Zealand shall, in the midst of a vast solitude, take his stand on a broken arch of London Bridge to sketch the ruins of St. Paul's.

This was one of the opening remarks made by Thomas Babington Macaulay in his essay for the Edinburgh Review in $1840^{37}$ of a new English translation of von Ranke's History of the Popes. ${ }^{38}$ Macaulay was an evangelical Protestant who, nevertheless, greatly admired the Church of Rome. The key point for our purposes is that Macaulay was keenly impressed by the Church of Rome's ability to endure. It already had a long history and as far as he could see was set to survive for centuries more. The reason the Roman Catholic Church enjoyed such success and longevity was that it coped with dissent in an effective and pro-active way compared to the various Protestant faiths. Of particular note here for Macaulay is the lesson that should be learned from this long-lasting success by England. Compared to the endurance of the Church of Rome, Macaulay envisioned the Church of England and its subsequent political and constitutional consequences as something far more flimsy and less likely to endure.

The endurance of Macaulay's apocalyptic vision might well have surprised the author himself. Indeed, the survival of his premonition can be attributed, at least in part, to its 
visualisation by Gustave Doré several decades later. The French artist gives us a foreigner's view of the first city of Empire where the importance of its ruins is matched by the recognition of its economic might. ${ }^{39}$ Whereas for Doré the architectural fragments of the 'new Rome' can speak for themselves, he articulates the large warehouse, which also forms part of the New Zealander's view, with the words 'Commercial Wharf'. The late nineteenth-century, Anglo-French perspective of Doré's gloss on Macaulay's commentary has steered it towards being seen as a critique of empire and as a symptom of crosschannel rivalry. ${ }^{40} \mathrm{My}$ concern is different and I wish to concentrate on the context for Macaulay's words and Doré's illustration, particularly here the choice of ruins and what they might mean as allegory. Here I am thinking of Benjamin's concept of 'allegorical sensibility' as a critical tool that relates to the historical world. Macaulay's ruins are, then, a method or a way of seeing that focuses on impermanence and lived experience and the ephemeral nature of existence.

Macaulay's prediction of London's future as a ruin belongs to an established literary preoccupation. ${ }^{41}$ Arguably never short of an opinion, Horace Walpole typifies this tradition in his remark:

The next Augustan age will dawn on the other side of the Atlantic. There will perhaps be a Thucydides at Boston, a 
Xenophon at New York, and in time a Virgil at Mexico, and a Newton at Peru. At last some curious traveller from Lima will visit England and give a description of the ruins of St. Paul's, like the editions of Balbec and Palmyra - but am I not prophesying contrary to my consummate prudence, and casting horoscopes of empires like Rousseau? Yes; well, I will go and dream of my visions. ${ }^{42}$

Similar visions were described by Percy Bysshe Shelley in his Dedication of Peter Bell the Third:

[...] when London shall be an habitation of bitterns; when St. Paul's and Westminster Abbey shall stand, shapeless and nameless ruins, in the midst of an unpeopled marsh; when the piers of Waterloo Bridge shall become the nuclei of islets of reeds and osiers, and cast the jagged shadows of their broken arches on the solitary stream, some transatlantic commentator will be weighing in the scales of some new and now unimagined system of criticism, $\ldots^{43}$

The notion of the foreign (i.e. non European) commentator certainly finds reprise in Macaulay's New Zealander. And this again is part of a substantial body of thought about how historians/archaeologists/antiquarians of the future will write 
history. The otherness or non-Europeanness of these imagined creators of the imagined past at some point in the imagined future is a common thread. Much has been made of these writings as being indexical of anxieties about the British Empire and the American Revolution. ${ }^{44}$ But I prefer the temporal and spatial irony lent to these anxieties through the projected ruin of London Bridge. When Macaulay placed his New Zealander on the ruins of the then very modern London Bridge that had just been rebuilt in the 1820s he could not have foreseen its future demolition. Nor could he have predicted its reconstruction as a tourist attraction in Arizona - part of the new world and former empire. ${ }^{45}$ However, my concern here is rather different; it is about how ruins are used to project identities into the future. Returning, then, to Soane and his Crude Hints, we find he was not alone in wondering how antiquarians of the future might explain the remains of modern London. Nor were these visions of ruination confined to masculine authors. In 1800 Elizabeth Lady Holland recorded in her journal:

I have been reading Le Brun's journey to Persepolis in 1704, the ruins of which (Persepolis) seem equal to anything in antiquity in point of solidity, size, and extent. In future times when this little island shall have fallen into its natural insignificancy, by being no longer possessed of a fictitious power founded upon commerce, distant 
colonies, and other artificial sources of wealth, how puzzled will the curious antiquary be when seeking amidst the ruins of London vestiges of its past grandeur? Acres now covered by high, thin walls of brick, making streets tirés à cordon, divided into miserable, straitened, scanty houses, will, when decayed, crumble into a vast heap of brick-dust. No proud arch to survive the records of history, no aqueduct to prove how much the public was considered by ye Governt., no lofty temples, no public works! St. Paul's anywhere would be a grand edifice; finer as a ruin than in its present state, disfigured with casements, whitewashed walls, pews, etc. The bridges alone would strike the eye as fine remains; they are magnificent. ${ }^{46}$

Whether foreign or not the imagined historians of the future are given a distance and remoteness from the imagined ruins they confront. This temporal and cultural gap is akin to that experienced by the Grand Tourists who viewed the ruins of Rome. In this way the choice of St Paul's Cathedral, London Bridge and The Bank of England become ideological deposits that speak to a present and future identity for the City of London. As such these buildings are no less monumental or meaningful as ruins. Ruination does not necessarily entail a loss, but rather a shift in the meaning of architecture. Benjamin helps us to discover these changes. 


\section{Benjamin}

Allegories are, in the realm of thoughts, what ruins are in the realm of things. ${ }^{47}$

In The Origin of German Tragic Drama, Benjamin champions the position of allegory in the age of the Baroque as in his view it has been side-lined by the preoccupation with beauty, particularly the aesthetic symbol. The ruin is fundamental here as it is the physical effect or manifestation of allegory. Importantly for us, allegory was criticised for its lack of fixity of meaning as it revealed the multiplicity of meanings inherent in an object. Benjamin's response to this was to see allegory as a method or a way of seeing and consequently it becomes a critical tool that relates to the historical world. Temporality is also important here as Benjamin's concept of 'allegorical sensibility' focuses on impermanence and lived experience, with an emphasis on the ephemeral nature of existence.

In the ruin history has physically merged into the setting. And in this guise history does not assume the form of the process of an eternal life so much as that of irresistible decay. Allegory thereby declares itself to be beyond beauty. ${ }^{48}$ 
For Benjamin the realm of thought is historical and this calls in to question its relationship to the actual. Allegory or history encapsulate the abstract ideals of a culture and these representations challenge our notion of what is credible. In this way, allegory can become intertwined with opposing sets of cultural values and we see this in Soane and Macaulay's allegories of future memory and history about London. Their invented visions, which appear to draw heavily on inspiration from an invented past, disrupt our notions of memory and history. In one way, Macaulay's New Zealander and the representation of the Bank of England as a ruin links us to the past in an unmediated way as they embody the unquestioned social rituals and cultural practices of the Grand Tourists who visited Rome. As such, this kind of memory enjoys continuity with the eternal present and an imagined future. But this spontaneity contradicts and challenges an imagined future history. History is always an incomplete reconstruction from fragments. It is a means by which societies assemble the past through sifting and organising historical traces into patterns in the face of constant progress or change. Architecture, in our case the City of London, plays into this as it is a physical site that gives place to traditions and social rituals - it remains in the present bringing with it its past and linking us to it and projecting itself and us into the future. Soane and Macaulay's 
ruins work, then, in a Benjaminian sense, as they are allegories that both document the ruination of the tradition that they also work to construct. The ruins of the City of London operate, then, as an historical palimpsest of the fragments of a future, invented memory.

\section{Notes}

My thanks to the editors and the anonymous reader for their incisive comments.

${ }^{1}$ There are many studies of antiquarian culture and the relationship between English architecture and ancient ruins, especially Rome. On the former, see for instance, M Myrone and L Peltz (eds) Producing the Past: Aspects of Antiquarian Culture and Practice, 1700-1850, Aldershot, Ashgate, 1999. On the latter, see for instance, C Edwards (ed) Roman Presences: Receptions of Rome in European Culture, 1789-1945, Cambridge, Cambridge University Press, 1999, M. Liversidge and C Edwards (eds) Imagining Rome: British Artists and Rome in the Nineteenth Century, London, 1996 and F Salmon, Building on Ruins: The Rediscovery of Rome and English Architecture, Aldershot, Ashgate, 2000.

${ }^{2}$ For a full discussion of the urban development of London in the early nineteenth century see for instance J Summerson, John Nash Architect to King George IV, London, 1949; J Summerson, Georgian London, Harmondsworth, (3rd edition) 1977; and D Arnold, Rural Urbanism: London landscapes in the early nineteenth century, Manchester, Manchester University Press, 2005

${ }^{3}$ The Mechanics Magazine, 1827

${ }^{4}$ See 'The Pantheon', in F H W Sheppard (ed), Survey of London: Volumes 31 and 32, St James Westminster, Part 2, London, 1963, pp. 268-283. 
${ }^{5}$ The Colosseum is discussed in D Arnold, Rural Urbanism: London landscapes in the early nineteenth century, MUP 2006 and D Arnold, Panoptic Visions or Possessing the Metropolis, Art History, vol 32, no 2, 2009 pp 332-350

${ }^{6}$ See, for instance, Anne Janowitz, England's Ruins: Poetic Purpose and the National Landscape, Cambridge MA and Oxford, Blackwell, 1990. On p.4 Janowitz remarks '[T]he building of a national identity is closely linked to the sense of some earlier or some other nation's ruin'. See also D Arnold (ed) The Metropolis and its Image: Constructing Identities for London 1750-1950, Oxford Blackwell 1999 also published as a special issue of Art History, vol 22 no 4, 1999

${ }^{7}$ Thucydides, History of the Peloponnesian War, Book 1. Chapter 10.

Paragraph 2 trans Richard Crawley, London, 1874 (Thucydides 1.10.2)

${ }^{8}$ Edmund Burke, A Philosophical Enquiry into the Origin of Our Idea of the Sublime and Beautiful, (1757), (1767 5th ed) London J Dodsley in Pall-mall p.77

${ }^{9}$ Edmund Burke, A Philosophical Enquiry into the Origin of Our Idea of the Sublime and Beautiful (1757), (1767 5th ed) London J Dodsley in Pall-mall Part I Sect XV On the effect of Tragedy pp75-79

${ }^{10}$ Edmund Burke, A Philosophical Enquiry into the Origin of Our Idea of the Sublime and Beautiful, (1757), (1767 5th ed) London, J Dodsley in Pall-mall, Part I Sect XV 'On the effect of Tragedy' p.75 and p.77.

${ }^{11}$ For a discussion of Soane and Gandy see B Lukacher, 'Sir John Soane and His Draughtsman Joseph Michael Gandy’ Diadalos 25 (15 Sept.), 1987, pp51-64 and B Lukacher, Joseph Gandy: An Architectural Visionary in Georgian England, London, Thames and Hudson, 2006

12 On Soane's use of the 'archaeological metaphor' see Jaś Elsner

'Architecture, Antiquarianism and Archaeology in Sir John Soane's Museum' in A. Tsingarida and D. Kurtz (eds.), Saisir 
l'antique/Appropriating Antiquity, Brussels, University of Brussels Press, 2002, pp.165-216.

${ }^{13}$ T. B. Macaulay, review of Leopold von Ranke, The Ecclesiastical and Political History of the Popes During the Sixteenth and Seventeenth Centuries, trans. S. Austin, London, 1840, in Edinburgh Review 72, October 1840, pp. 227-58.

${ }^{14}$ See D Arnold 'London Bridge and its Symbolic Identity in the Regency Metropolis: The dialectic of civic and national pride', Art History, vol 22 no 4, 1999, pp 545-566.

${ }^{15}$ Walter Benjamin, The Origin of German Tragic Drama, trans. John Osbourne, New York and London, Verso, 1977, pp. 177-78

16 There are many studies of Soane's life and work. In addition to publications cited else where see, for instance, P de la Ruffinière du Prey, John Soane: the Making of an Architect, Chicago, University of Chicago Press, 1982; M Richardson and M A Stevens, (eds), John Soane Architect, London, Royal Academy 1999 ( $2^{\text {nd }}$ ed 2015).

${ }^{17}$ For Soane's work for the Office of Works see J. M. Crook and M. H. Port (eds), The History of the King's Works: Vol. VI: 1782-1851, HMSO,

London, 1973

${ }^{18}$ Dorothy Stroud, Sir John Soane Architect, London, Faber \& Faber, 1984 p. 151

${ }^{19}$ Gillian Darley, John Soane An Accidental Romantic, New Haven and London, Yale University Press, 1999 p.304

${ }^{20}$ For a full discussion of Soane's work at the Bank of England see Eva Schumann-Cacia, John Soane and The Bank of England, London, Longman, 1991; Daniel M. Abramson, PhD thesis 'The Building of the Bank of England', (Harvard, 1993), pp.425-9; Daniel M. Abramson. Building the Bank of England: Money, Architecture, Society, 1694-1942. New Haven and London: Yale University Press, 2005 
${ }^{21}$ For a discussion of Soane's House/Museum see, for instance, S FeinbergMillenson, Sir John Soane's Museum, Ann Arbor, UMI Research Press, 1987, pp 1-76 esp.

${ }^{22}$ There is a vast literature on Soane's house/museum. See for instance, J Elsner, ‘A Collector's Model of Desire: The House and Museum of Sir John Soane', in ed. J Elsner and R Cardinal (eds), The Cultures of Collecting, London, 1994 pp155-176

$233^{\circ}$ Gul.IV, Cap.iv

${ }^{24}$ Soane's Professorship at the Royal Academy and the contents of his lectures can be found in David Watkin, Sir John Soane Enlightenment Thought and the Royal Academy Lectures, Cambridge, Cambridge University Press, 1996

${ }^{25}$ Abramson Bank of England Yale UP, 2005, op.cit. p.222

${ }^{26}$ On this point see D Arnold, 'Facts or Fragments? Visual histories in the age of mechanical reproduction', Art History, vol 25 no 4, 2002, pp

${ }^{27}$ On the relationship between ruins and aesthetics see for instance Karen Lang, 'The Dialectics of Decay: Rereading the Kantian Subject', The Art Bulletin, vol. 79, September 1997, pp. 413-39

${ }^{28}$ On Piranesi and Clérisseau see for instance T J McCormick, Charles-Louis Clérisseau and the Genesis of Neo-Classicism, Cambridge, Mass. MIT, 1990 and J Wilton-Ely, The Mind and Art of Giovanni Battista Piranesi, London 1978

${ }^{29}$ Soane owned 15 original Piranesi drawings for Paestum which he displayed in his Picture Room. Interestingly, they were hung interspersed with other works: oil paintings, prints and watercolours.

${ }^{30}$ D Arnold, 'Facts or Fragments? loc cit

${ }^{31}$ Although completely different in terms of ideology, Soane's concern that his architecture would also look good when in ruins has some resonance with Albert Speer's notion of a 'law of ruin value' (Ruinengesetz), that would provide a 'bridge of tradition' for posterity. On this point see Alex Scobie, 
'Albert Speer's Theory of Ruin Value' in Hitler's State Architecture: the Impact of Classical Antiquity, University Park, Pennsylvania State University Press, 1990 pp 93-96. The relationship between Speer and Walter Benjamin’s value of ruins is explored in Naomi Stead, 'The Value of Ruins: Allegories of Destruction in Benjamin and Speer', Form/Work: An Interdisciplinary

Journal of the Built Environment, no. 6, October 2003, pp. 51-64.

32 The cult of the ruin has attracted a vast literature. See for instance, Julia

Hall and Andreas Schoenle eds., Ruins of Modernity, Durham, Duke University Press, 2010; Christopher Woodward, In Ruins, London, Chatto \& Windus, 2001; Anne Janowitz op cit.; Laurence Goldstein, Ruins and Empire: the Evolution of a Theme in Augustan and Romantic Literature, Pittsburgh, PA, University of Pittsburgh Press, 1977 and Rose Macaulay, The Pleasures of Ruins, London,1953

${ }^{33}$ For a discussion of William Kent and Robert Adam's designs for follies see Visions of Ruin: Architectural Fantasies and Designs for Garden Follies, Exhibition Catalogue Soane Museum, London, 1999

${ }^{34}$ Soane's own description of Pitzhangar is discussed in Jaś Elsner

‘Architecture, Antiquarianism and Archaeology in Sir John Soane’s Museum' loc cit. pp191-196 esp.

35 This is a manuscript in Soane's hand, dated $30^{\text {th }}$ August $-22^{\text {nd }}$ September 1812. The manuscript was laid out in several columns, with annotations on the right hand side. Soane's text was not published until 1999 when it appeared with annotations by Helen Dorey as part of the exhibition catalogue Visions of Ruin published by The Soane Museum see H. Dorey in Visions of Ruin: Architectural Fantasies and Designs for Garden Follies, Exhibition Catalogue Soane Museum, London, 1999. A revised and updated edition, edited by Helen Dorey was published in 2015 by Archaeopress.

${ }^{36}$ Ludwig Wittgenstein, Culture and Value 4e edited by $\mathrm{G} \mathrm{H}$ von Wright Culture and Value: A Selection of the posthumous remains Oxford Blackwell 1998 page 24 
${ }^{37}$ Edinburgh Review, October 1840 (loc. cit) and 'Foreign History' section of Volume II of TB M's Critical and Historical Essays, Boston, Mass., 1855.

The quoted passage appears in paragraph three of Macaulay's lengthy review. Other authors have claimed it forms part of the closing remarks.

${ }^{38}$ Leopold von Ranke, The Ecclesiastical and Political History of the Popes of Rome, during the Sixteenth and Seventeenth Centuries, by Sarah Austin trans. 3 vols. London, 1840.

${ }^{39}$ Doré completed his wood-engraving in 1869 . It was only published two years later in Gustave Doré and Blanchard Jerrold 'Macaulay's New Zealander' in London: A Pilgrimage, 1871-72. Doré's image appeared in Louis Énault Londres, 1876, accompanied by a new French text.

${ }^{40}$ On this point see, for instance, David Skilton, 'Gustave Doré's London/Londres: empire and post-imperial ruin,' Word \& Image: A Journal of Verbal/Visual Enquiry, vol 30, Issue 3, 2014, pp. 225-237, and for a more general discussion A Woods, 'Doré's London: Art and Evidence,' Art History vol1 no 3, 1978 pp 341-359. My thanks to Sam Bibby for the latter reference.

${ }^{41}$ Debates about Macaulay's sources and who was the first to describe London in ruins for several years after publication of his review. See for instance E. Littell ed., 'Macaulay and Kirke White', A Panorama of Life and Literature, vol 1 July-December Boston Mass., 1855, p143. An article from the New York Times is quoted claiming Kirke White as the original inspiration for Macaulay rather than Shelley (see note 21).

${ }^{42}$ Horace Walpole to Horace Mann, 24 November 1774, in The Yale Edition of Horace Walpole's Correspondence, W.S. Lewis et al. eds., 48 vols. Oxford, Oxford University Press, 1937- 1983 vol. XXIV (1967), p.62.

${ }^{43}$ Written in 1819 , but not published until 1839 , Peter Bell the Third is a demonic parody of Wordsworth's poem Peter Bell (1819). Part III begins with the well-known phrase, 'Hell is a city much like London'. 
${ }^{44}$ On this point see, for instance, Janowitz (op. cit.); David Skilton, 'Tourists at the Ruins of London: The Metropolis and the Struggle for Empire' Cercles 17, 2007, pp. 93-119.

${ }^{45}$ On the rebuilding of London Bridge in 1820s see D Arnold 'London Bridge and its Symbolic Identity in the Regency Metropolis: The dialectic of civic and national pride', Art History, vol 22 no 4, 1999, pp 545-566. The resiting of this version of London Bridge to Lake Havsu City, Arizona is discussed in D Arnold, 'London Bridge Revisited' in D Arnold and A Ballantyne (eds) Architecture as Experience London, Routledge, 2004 pp $261-276$

${ }^{46}$ Elizabeth Vassall, Baroness Holland, The Journal of Elizabeth Lady Holland, G.S.H. Fox-Strangways, Earl of Ilchester ed., 2 vols, London, Longmans, Green \& co 1908, vol. 2, p. 54.

${ }^{47}$ Walter Benjamin, The Origin of German Tragic Drama, trans. John Osborne, New York and London, Verso, 1977, pp. 177-78.

${ }^{48}$ Benjamin, op. cit, p. 178 